DEPÓSITO LEGAL ZU2020000153

Esta publicación científica en formato digital

es continuidad de la revista impresa

ISSN 0041-8811

E-ISSN 2665-0428

Revista

de la

Universidad

del Tunlia

Fundada en 1947

por el Dr. Jesús Emrique Lossada

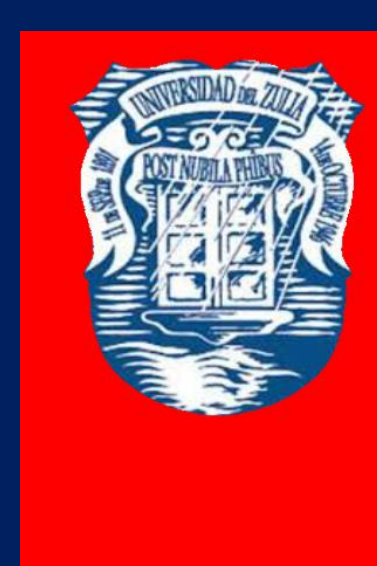

Ciencias

Sociales

y Arte

Aกัต 11 No 31

Septiembre - Diciembre 2021

Tercera ípoca

Maracailbo-Venezuela 


\title{
Remote education development trends during pandemic in Russia
}

\author{
Elena E. Kabanova* \\ Ekaterina A. Vetrova** \\ Tatiana A. Evstratova*** \\ Liudmila E. Radchenko***
}

\begin{abstract}
Currently, the higher education system in Russia is in the midst of rapid changes associated with the fundamental problems of organizing the educational process during a pandemic. The pandemic of the new coronavirus infection COVID-19 in 2020 affected the educational system around the world, causing the massive closure of higher education institutions. Among the management practices of Russian universities related to the provision of security for students and staff, key decisions and recommendations based on a large-scale transition to the use of e-learning, distance learning technologies and the transition to a distance learning format, which has changed the usual way of life of university students and teachers. The objective of this research is to evaluate the transition of the educational process to distance education in the context of the pandemic, to identify the factors that hinder the development of learning. The research method is a questionnaire survey on distance learning using distance technologies in higher education. The results indicate that the development of a new model of education in universities can find resistance to external challenges and to a more productive way for economic and social development.

KEYWORDS: higher education, higher education institutions, distance education, distance education technologies, students, distance education programs, educational platform.
\end{abstract}

${ }^{*}$ Candidate of Sociological Sciences, Associate Professor at the Faculty of Management. Russian State Social University, The Russian Federation, Moscow. ORCID: https://orcid.org/0000-00029983-8158. E-mail: cool90@list.ru

${ }^{* *}$ Candidate of Economic Sciences, Associate Professor at the Faculty of Management. Russian State Social University, The Russian Federation, Moscow. ORCID: https://orcid.org/0000-0002-77931888. E-mail: eavetrova@yandex.ru

${ }^{* * *}$ Candidate of Sociological Sciences, Associate Professor at the Faculty of Management, Russian State Social University, The Russian Federation, Moscow. ORCID: https://orcid.org/0000-00028737-3218. E-mail: doroshenkot@yandex.ru;

${ }^{* * * *}$ Candidate of Sociological Sciences, Russian language teacher, Lyceum named after Jam Saheb Digvijay Sinhji, Polska, Warszawa. ORCID: https://orcid.org/0000-0001-6777-1617. E-mail: r576987107@gmail.com 


\section{Tendencias de desarrollo de la educación a distancia durante la pandemia en Rusia}

RESUMEN

Actualmente, el sistema de educación superior en Rusia se encuentra en medio de rápidos cambios asociados con los problemas fundamentales de la organización del proceso educativo durante una pandemia. La pandemia de la nueva infección por coronavirus COVID-19 en 2020 afectó al sistema educativo en todo el mundo, lo que provocó el cierre masivo de instituciones de educación superior. Dentro de las prácticas de gestión de las universidades rusas relacionadas con la provisión de seguridad para los estudiantes y el personal, destacan las decisiones y recomendaciones clave basadas en una transición a gran escala al uso de elearning, tecnologías de aprendizaje a distancia y la transición a un formato de aprendizaje a distancia, que ha cambiado la habitual forma de vida de los estudiantes y docentes universitarios. El objetivo de esta investigación es evaluar la transición del proceso educativo para la educación a distancia en el contexto de la pandemia, para identificar los factores que dificultan el desarrollo del aprendizaje. El método de investigación es una encuesta de cuestionario sobre el aprendizaje a distancia que utiliza tecnologías a distancia en educación superior. Los resultados indican que el desarrollo de un nuevo modelo de educación en las universidades puede encontrar resistencia ante los desafíos externos y a una forma más productiva para el desarrollo económico y social.

PALABRAS-CLAVE: educación superior, instituciones de educación superior, educación a distancia, tecnologías de educación a distancia, estudiantes, programas de educación a distancia, plataforma educativa.

\section{Introduction}

Distance learning started as the result of information and communication technology development and their use in many areas of life, including education.

Recently, humanity has become a prisoner of electronic technology. Regardless of gender, age, educational level, ethnicity, economic status, modern people actively use gadgets in their lives that allow them to access any information quickly, constantly be in touch with friends, relatives, colleagues, regardless of the interlocutor location (Kabanova, E.E., and Vetrova, E.A. 2019).

Information and communication technologies that have been developed and are being developed penetrate into all spheres of human activity. Everyone is faced with these technologies, both at work and at home. Of course, information and communication technologies have not bypassed the field of education and have led to the fact that the process 
REVISTA DE LA UNIVERSIDAD DEL ZULIA. $3^{a}$ época. Año 11 N 31, 2020

Elena E. Kabanova et al/// Remote education development trends during pandemic in Russia, 536-549

DOI: http://dx.doi.org/10.46925//rdluz.31.35

of obtaining education has improved. Innovative activity in education is considered not only as a factor of its quality and efficiency improvement, but also as a factor of demand increase for educational services and changes in the motivational readiness of the population to learn throughout life.

Distance learning began its development in Russia in the early 1990-ies. On May 30, 1997, the order No. 1050 of the Ministry of Education of Russia was issued, which made it possible to conduct an experiment of distance learning in the field of education. This date can be considered the official date of distance learning birth.

Currently, in the 16th Art. of the Law "On Education in the Russian Federation", the term "e-learning" is enshrined, which includes the organization of educational activities using information contained in databases and used in the implementation of educational programs and its processing, information technologies, technical means, as well as information and telecommunication networks ensuring the transfer of the specified information through communication lines, the interaction of students and pedagogical workers. The definition of the concept of "distance educational technologies" is also given - educational technologies implemented mainly with the use of information and telecommunication networks with indirect (distant) interaction between students and teachers." (Oleinik, E.V., et al. 2020).

The term "distance learning" means such an organization of the educational process in which a teacher develops a curriculum, mainly based on the student's self-study. Such a learning environment is characterized by the fact that the student is mainly, and often completely separated from the teacher in space or time; at the same time, students and teachers have the opportunity to carry out a dialogue with each other using telecommunications. Distance learning allows the residents of regions to study, where there are no other opportunities for professional training or obtaining high-quality higher education, there is no university of the required profile or the teachers with the required level of qualifications (Rodina, E.A. 2020).

The main principles of distance learning are the following: the ability to establish online communication between students and teachers, without the possibility of their personal communication, as well as independent study of a certain area of knowledge by students, the acquisition of skills in a chosen subject according to the curriculum using information and electronic technologies. 
REVISTA DE LA UNIVERSIDAD DEL ZULIA. $3^{a}$ época. Año 11 N 31, 2020

Elena E. Kabanova et al/// Remote education development trends during pandemic in Russia, 536-549

DOI: http://dx.doi.org/10.46925//rdluz.31.35

The main problem in the development of distance learning is the creation of new teaching methods and technologies that meet the telecommunications environment of communication. In this environment, the fact is clearly manifested that students are not just passive consumers of information, but they create their own understanding of the education subject content in the learning process. (Shmurygina, O.V. 2020).

Distance learning is somewhat different from the usual forms of full-time or part-time education. It presupposes a different form of interaction between a student and a teacher, other methods and means of the educational process conduct and an organizational form of training. However, any organizational form of student full-time, part-time, and distance training, have the same goals and objectives, determined by the current training programs for a particular educational institution.

The main differences between distance education and full-time education are the following:

- The mode of teaching students is built in accordance with the place of residence or work;

- The schedule of the educational process changes in accordance with the course of study and can be sufficiently free in open education, or tied to a limited number of checkpoints (passing exams, online sessions with a teacher), or to group lessons, or to laboratory work on the equipment that may even be remote;

- The contacts with a teacher are established through telecommunications.

The main differences between distance education and correspondence education are the following:

- Constant contact with a teacher, the ability to promptly discuss emerging issues with him, as a rule, using telecommunications;

- The possibility of discussion organization, general work on plans during the educational course study;

- The transfer of theoretical materials to students in the form of printed or electronic teaching aids, which allows either to completely abandon the setting sessions upon arrival at a university, or to reduce their number and duration significantly (Vladimirovna, 2012).

The coronavirus pandemic has launched a digital transformation of the educational process at all its levels, and it is happening much faster than it has been planned for the past few years within the framework of various national projects. We were ready for some of its 
REVISTA DE LA UNIVERSIDAD DEL ZULIA. $3^{a}$ época. Año 11 N 31, 2020

Elena E. Kabanova et al/// Remote education development trends during pandemic in Russia, 536-549

DOI: http://dx.doi.org/10.46925//rdluz.31.35

features, but not very much for others. One thing can be said for sure: digitalization is no longer the future, it is our reality (Mikhailovna, 2016).

To increase the level of technologization of the educational process remotely, students need to equip a workplace at home. For this purpose, they need to purchase:

- Stationary computer, laptop, tablet or smartphone.

- For distance learning, communication with teachers, you can use video communication services: Zoom, Cisco Webex Meetings, Skype, Google Hangouts, UberConference, FreeConference, Jitsi, ezTalks, Discord messenger, and the popular Facebook Messenger also allow you to communicate via video communication.

- Internet from $10 \mathrm{Mbps}$ to 20 Megabits/sec. for video calls, video conferencing, through the above services and messengers, for downloading photo and video materials, watching video in $4 \mathrm{~K}$ quality, etc.

- Webcam - for communication and participation in conferences;

- Microphone - to enable communication with a teacher.

When there was just talk about the education system transfer to distance learning, everyone understood perfectly well that the very organization of traditional classes should be carried out in other ways and in other forms.

A teacher working in the distance learning system performs the following main functions: provides assignments, tests and other auxiliary materials for the course; answers questions in forums and chats; checks coursework, test and exam papers of students; controls the student work by monitoring educational activity and progress (Arkadyevna, 2013).

Nowadays the main technologies of distance learning are the conduct of classes online through videoconference, the use of video lessons directed by a teacher to a student, also via the Internet and posted on the portal of the educational institution for each lesson, the distribution of didactic training material for the study of which a student must test his knowledge and skills by going through a series of test tasks to assess his level of knowledge and point out mistakes.

Modern development of technology, in particular, the use of Skype for teaching, the use of which allows the student to see and hear the teacher's lesson, as well as the materials that he shows to the student during the lesson on the computer screen. 
REVISTA DE LA UNIVERSIDAD DEL ZULIA. $3^{a}$ época. Año 11 N 31, 2020

Elena E. Kabanova et al/// Remote education development trends during pandemic in Russia, 536-549

DOI: http://dx.doi.org/10.46925//rdluz.31.35

This became possible due to the Internet development, on which all distance education technologies are based (Leonidovna, 2015).

The informational richness of the modern world requires special preparation of educational material before its presentation to a learner. There is a need for substantiation and active implementation of a special technology that makes it possible to solve the problems of assembling knowledge and its operational use. To the greatest extent, this problem can be solved by educational information visualization technology, which is based on various effective methods of data processing and assembling, which allow to "compress" it, that is, present in a compact, convenient form for use (Valery Falkov).

At the moment the distance format in Russia is a new option in the field of higher education. Its popularity and demand will depend on a number of factors: on the availability of the Internet in the regions of Russia, on the positioning of distance learning by universities, on the political and economic situation in Russia, and on other factors (Nikolaevna, 2015).

The objective of this study is to survey the progress of the instructive cycle to separate learning in a troublesome circumstance inside a pandemic, just as to distinguish the elements obstructing the advancement of separation learning.

Analysis of recent publications on the problem

The issues of a theoretical and methodological nature, as well as the trends in the development of distance education in Russia within the field of higher professional education, are considered in the works of such Russian authors as Veselitsky, O., and Khabarov, D. (2019), Vishnevskaya Galina Vladimirovna (2012), Pekker Polina Leonidovna. (2015), Rodina, E.A. (2020), and Shmurygina, O.V. (2020).

The development of distance learning technologies in a modern higher educational institution is considered in the works of such Russian authors as Murtazina, G. Kh. (2010).

The problems of student adaptation during the transition of a university to distance learning in a pandemic are considered in the works of such Russian authors like Oleinik, E.V., et al. (2020).

\section{Materials and Methods}

The empirical basis of the study was the results of a sociological study conducted by the authors in the spring of 2020 during the Coronavirus Pandemic on the basis of the Russian State Social University (RSSU). The respondents were the students of the Faculty 
REVISTA DE LA UNIVERSIDAD DEL ZULIA. $3^{a}$ época. Año 11 N 31, 2020

Elena E. Kabanova et al/// Remote education development trends during pandemic in Russia, 536-549

DOI: http://dx.doi.org/10.46925//rdluz.31.35

of Management at the RSSU $(\mathrm{N}=100)$. They used a systematic probability sampling. The sampling frame was a list of undergraduate students in alphabetical order, the Faculty of Management, the courses 1-3.

The research toolkit is a questionnaire survey on distance learning using distance technologies in obtaining higher education, to which the RSSU switched because of a new coronavirus infection spread threat.

The purpose of this study was to assess the transition of the educational process to distance learning in a difficult situation within a pandemic, as well as to identify the factors hindering the development of distance learning.

The results of the survey of students showed that within a pandemic, in order to obtain education successfully, it was necessary to switch from traditional classes to distance learning.

During carrying out scientific work, general scientific research methods were applied in addition to the survey based on general principles in order to apply general laws to specific factors related to the educational activities of higher educational institutions, special and indepth study of statistical data analysis aspects, the method of analogy, generalization and extrapolation.

When writing the article, they used widely such methods of the theoretical level as modeling, systematization, classification, formalization and other methods, on the basis of which they studied the level of demand for distance learning among students of the Faculty of Management of the Russian State Social University. They ordered the factors influencing the quality of education received remotely.

In addition, the information base was the results of research by the All-Russian Center for the Study of Public Opinion (VTsIOM) on the following topic: "Satisfaction with the organization of distance education, changes in the level of workload and possible consequences that may affect the quality of education due to the transition to a remote learning format" (March, 2020).

\section{Results}

In the course of the study of the educational process transition to distance learning, in the context of a pandemic, as well as the identification of the factors hindering the 
REVISTA DE LA UNIVERSIDAD DEL ZULIA. $3^{a}$ época. Año 11 N 31, 2020

Elena E. Kabanova et al/// Remote education development trends during pandemic in Russia, 536-549

DOI: http://dx.doi.org/10.46925//rdluz.31.35

development of distance learning, it is required to identify the factors influencing it. It is natural to assume that the higher the level of technologization, the higher the degree of satisfaction.

This hypothesis is very easy to test by constructing a two-dimensional contingency table.

Table 1 . Analysis of contingency tables using the chi-square test

\begin{tabular}{llll}
\hline \multirow{2}{*}{ Factor sign } & \multicolumn{2}{c}{ Resulting sign } & \multirow{2}{*}{ Sum } \\
\cline { 2 - 3 } & Yes & No & \\
\hline $\begin{array}{l}\text { Impact of technology on distance learning } \\
\begin{array}{l}\text { Impact of distance learning on the } \\
\text { development of computer skills }\end{array}\end{array}$ & 76 & 24 & 100 \\
\hline Increased workload on teachers & 55 & 45 & 100 \\
\hline $\begin{array}{l}\text { Increased workload on students } \\
\text { Distance teaching level: high/low }\end{array}$ & 51 & 49 & 100 \\
\hline $\begin{array}{l}\text { Assessment of the educational institution } \\
\text { level concerning the equipment necessary } \\
\text { for conducting classes in a remote format: } \\
\text { high/low }\end{array}$ & 92 & 28 & 100 \\
\hline $\begin{array}{l}\text { Are there any restrictions that prevent } \\
\text { students from mastering knowledge? }\end{array}$ & 2 & 8 & 100 \\
\hline \begin{tabular}{l} 
Total: \\
\hline
\end{tabular} & 430 & 98 & 100 \\
\hline
\end{tabular}

After the survey, it was found that $72 \%$ of respondents were satisfied with the organization of distance education, and every fourth noted an extreme degree of satisfaction from the organization. $26 \%$ of respondents expressed their dissatisfaction with the organization of the distance learning process, and 5\% of them have an extreme degree of dissatisfaction, $2 \%$ of respondents found it difficult to answer the question.

The level of equipping the educational institution with the equipment necessary for distance learning organization was assessed as high - 38\%, low - 38\%, medium - 19\%, and 5\% of the respondents found it difficult to answer. 
REVISTA DE LA UNIVERSIDAD DEL ZULIA. $3^{a}$ época. Año 11 N 31, 2020

Elena E. Kabanova et al/// Remote education development trends during pandemic in Russia, 536-549

DOI: http://dx.doi.org/10.46925//rdluz.31.35

Table 2. The issues related with the transition to distance learning

Question / Proposed answer option

University

students

1. Taking into account all the parties, tell me, please, are you satisfied or not satisfied with the organization of distance education in your educational institution? (closed-ended question, one answer, \% of university students).

Completely satisfied 25

Rather satisfied 47

Rather not satisfied 21

Not satisfied completely 5

It is difficult to answer 2

2. What's your rate about the level of equipping your educational institution with the equipment necessary for organizing distance learning (high, low or medium)? (Closedended question, one answer, $\%$ of university students).

\begin{tabular}{lc}
\hline High & 22 \\
\hline Rather high & 16 \\
\hline Medium & 38 \\
\hline Rather low & 72 \\
\hline Low & 5 \\
\hline It is difficult to answer & 25 \\
\hline 3. What's your estimation concerning the level of teaching at your educational \\
institution in the distance format? (closed-ended question, one answer, \% of university \\
students) & 28 \\
\hline High & 32 \\
\hline Rather high & 8 \\
\hline Medium & 4 \\
\hline Rather low & 3 \\
\hline Low & 25 \\
\hline It is difficult to answer & \\
\hline
\end{tabular}


REVISTA DE LA UNIVERSIDAD DEL ZULIA. $3^{a}$ época. Año 11 N 31, 2020

Elena E. Kabanova et al/// Remote education development trends during pandemic in Russia, 536-549

DOI: http://dx.doi.org/10.46925//rdluz.31.35

4. In your opinion, has your study load changed or has it not changed after the transition to the distance learning format? And if it has changed, then has it increased or decreased? (Closed-ended question, one answer, \% of university students).

\begin{tabular}{lc}
\hline Increased significantly & 24 \\
\hline Rather increased & 27 \\
\hline Rather decreased & 6 \\
\hline Decreased significantly & 28 \\
\hline Has not changed, remained the same & 1 \\
\hline It is difficult to answer & 20 \\
\hline 5. In your opinion, has the workload of your educational institution teachers changed \\
or has not changed after the transition to the distance learning format? & And if it has \\
changed, then has it increased or decreased? (closed-ended question, one answer, \% of \\
university students) & 35 \\
\hline Increased significantly & 17 \\
\hline Rather increased & 2 \\
\hline Rather decreased & 20 \\
\hline Decreased significantly & 6 \\
\hline Has not changed, remained the same & \\
\hline It is difficult to answer &
\end{tabular}

Source: VCIOM http://www.wciom.ru

$53 \%$ of respondents noted a high level of teaching in an educational institution within a distance format, an average level $-32 \%$, a low level $-12 \%$, and $3 \%$ found it difficult to answer the question posed.

$51 \%$ of respondents noted the increase in student workload after the transition to distance learning, 20\% believe that the workload has decreased, 28\% think that the workload has remained at the same level, and $1 \%$ of respondents found it difficult to answer.

$55 \%$ of respondents noted teacher load increase after the transition to a distance learning format, 19\% believed that the load has decreased, 20\% believe that the load on teachers has not changed, $6 \%$ found it difficult to answer. 
REVISTA DE LA UNIVERSIDAD DEL ZULIA. 3é época. Año $11 N^{\circ}$ 31, 2020

Elena E. Kabanova et al/// Remote education development trends during pandemic in Russia, 536-549

DOI: http://dx.doi.org/10.46925//rdluz.31.35

\section{Discussion}

After analyzing the situation with the transition of the higher education system to distance learning during a pandemic, we conducted sociological surveys, analyzed the opinions of students and teachers about the forced change in basic processes, and identified problem areas.

The difficulties of transition to a new format of training were overcome thanks to the quickly created system of support for teachers. Many universities sent teachers the guidelines describing how to conduct remote video conferences with students. However, the workload on teachers was still quite high. Not all universities have created information platforms to inform and help teachers in the current mode.

Many of the most active teachers shared their knowledge on the possibilities of electronic resources with their colleagues, conducted training webinars for them, and used the possibilities of social networks for information.

$19 \%$ of the teaching staff at the time of the transition to distance learning were not provided with the necessary equipment for conducting classes.

Valery Falkov, the head of the Russian Ministry of Education and Science, commented on the transition to distance learning: "The higher education system coped with the transition to distance education largely due to the fact that teachers switched to almost individual work with students. At the same time, we understand that the load on all educational process participants has grown significantly." *

In this situation, the students provided significant assistance to their teachers during the transition to online learning. The teams of IT volunteers have been formed to help educators set up and use online platforms, and help resolve related technical issues.

Many educators noticed that new tools and practices of online learning were mastered due to this acute situation.

About 25\% of teachers actively using digital technologies before the pandemic were able to expand quickly the possibilities of familiar communication tool use and create digital resources for a distance learning format in a critical situation. 
REVISTA DE LA UNIVERSIDAD DEL ZULIA. $3^{a}$ época. Año 11 N 31, 2020

Elena E. Kabanova et al/// Remote education development trends during pandemic in Russia, 536-549

DOI: http://dx.doi.org/10.46925//rdluz.31.35

Conclusion

In modern conditions in Russia, higher education, career and professional growth are priority life values (Kabanova, E.E., and Vetrova, E.A. 2018). Now education is an integral part of our life, which shapes the future and professional skills, and, consequently, the labor market demand (Vetrova, E.A., et.al. 2019). Nowadays the development of the system of higher professional education is largely determined by the evolution of information transfer technologies. The formation of this area of knowledge establishes priority courses in the work of universities, one of which is the creation and constant expansion of the distance learning system for students.

Distance learning is widely used today in all forms of education at universities, and its use is supported by a number of approved regulatory legal acts and laws of the Russian Federation. It is believed that the progress in distance learning may undermine the position of traditional full-time student education. However, today distance learning is not able to replace full-time education completely.

The transition to distance learning during the pandemic has become a "stress test" for the higher education system. This experience forms a "window of opportunity" for the next step in the development of higher education.

Problems and tasks were identified that can only be solved thanks to digital technologies and distance learning. Teachers and students gained new experience, tested the possibilities of a different learning format and were able to work online.

The development of a new model of education in universities, taking into account the identified limitations and opened up opportunities, its approbation and the spread of new practices in the higher education system, which can become resistant to external challenges and a more productive way of the economy and society development.

\section{References}

Arkadyevna, N.N. (2013). on the possibilities of practical implementation of educational information visualization technology at the university. News of Altai State University, 2(78). URL: https://cyberleninka.ru/article/n/o-vozmozhnostyah-prakticheskogo-vnedreniyatehnologii-vizualizatsii-uchebnoy-informatsii-v-vuze (reference date: 16.07.2020). 
REVISTA DE LA UNIVERSIDAD DEL ZULIA. $3^{a}$ época. Año 11 N 31, 2020

Elena E. Kabanova et al/// Remote education development trends during pandemic in Russia, 536-549

DOI: http://dx.doi.org/10.46925//rdluz.31.35

Kabanova, E.E., and Vetrova, E.A. (2018). The Practice of Implementing Bologna Process in the Education Sector in the Russian Federation: Trends and Consequences. European Journal of Contemporary Education, 7(3), 511-520.

Kabanova, E.E., and Vetrova, E.A. (2019). The Use of Modern Electronic Gadgets in the Educational Process of the University. European Journal of Contemporary Education, 8(3), 524-533.

Leonidovna, P. P. (2015). Distance learning: experience of universities. Humanities, socioeconomic and social sciences, 6-2. URL: https://cyberleninka.ru/article/n/distantsionnoeobuchenie-opyt-universitetov (reference date: 08.06.2020).

Mikhailovna, P.K. (2016). Information technologies in distance learning // Science, technology and education, 8(26). URL: https://cyberleninka.ru/article/n/informatsionnyetehnologii-v-distantsionnom-obuchenii-2 (reference date: 18.07.2020).

Murtazina, G. Kh. (2010). The trends in the development of distance educational technologies. Bulletin of KazGUKI, 2. URL: https://cyberleninka.ru/article/n/tendentsiirazvitiya-distantsionnyh-obrazovatelnyh-tehnologiy (reference date: 08.06.2020).

Nikolaevna, A. T. (2015). Distance learning at the university. Bulletin of Sam. state tech. unty. Ser. Psychological and pedagogical sciences, 2(26). URL: https://cyberleninka.ru/article/n/distantsionnoe-obuchenie-v-vuze-l (reference date: 06/09/2020).

Oleinik, E.V., Mutalova, D.A., Bezenkova, T.A., and Manannikova, A.V. (2020). Studying the problem of university student adaptation in conditions of self-isolation to on-line learning with the use of distance educational technologies. Modern pedagogical education, 5. URL: https://cyberleninka.ru/article/n/izuchenie-problemy-adaptatsii-studentov-vuza-vusloviyah-samoizolyatsii-k-on-line-obucheniyu-s-primeneniem-distantsionnyh (reference date: 18.07.2020).

Rodina, E.A. (2020). Computer technologies in the educational process and distance education [Electronic resource]. - Access mode: http://www.jeducation.ru

Shmurygina, O.V. (2020). Educational process during a pandemic. Professional education and labor market. 2, 51-52. - DOI 10.24411/2307-4264-2020-10210

Valery Falkov, Head of the Ministry of Education and Science of Russia https://wciom.ru/index.php?id=236\&uid=10304

Veselitsky, O., and Khabarov, D. (2019). Trends in the development of distance education in Russia and abroad. Colloquium-journal, 3-3(27). URL: https:/cyberleninka.ru/article/n/tendentsii-razvitiya-distantsionnogo-obrazovaniya-vrossii-i-za-rubezhom (reference date: 08.06.2020). 
REVISTA DE LA UNIVERSIDAD DEL ZULIA. $3^{a}$ época. Año 11 N 31, 2020 Elena E. Kabanova et al/// Remote education development trends during pandemic in Russia, 536-549

DOI: http://dx.doi.org/10.46925//rdluz.31.35

Vetrova, E.A., Kabanova, E.E., Medvedeva, N.V., and Jukova, E.E. (2019). Management of Educational Services Promotion in the Field of Higher Education (the Example of "Russian State Social University"). European Journal of Contemporary Education, 8(2), 370-377.

Vladimirovna, V.G. (2012). The role of the Russian State Social University in the training of qualified personnel within the social sphere using distance educational technologies. Concept, 5. URL: https://cyberleninka.ru/article/n/rol-rossiyskogo-gosudarstvennogosotsialnogo-universiteta-v-podgotovke-kvalifitsirovannyh-kadrov-sotsialnoy-sfery-sispolzovaniem (reference date: 18.07.2020). 